Proc. Indian Acad. Sci., Vol. C 2, Part 3, September 1979, pp. 291-303. (C) Printed in India.

\title{
Hills, dams and forests. Some field observations from the Western Ghats
}

\author{
MADHAV GADGIL \\ Centre for Theoretical Studies, Indian Institute of Science, Bangalore 560012
}

MS received 2 May 1979

\begin{abstract}
Man's attempts to intensify the use of natural resources can often result in the exhaustion of the resource or deterioration of other interacting resources. The single-minded pursuit of the development of the water resources of the rivers of the Western Ghats shows many examples of this view, particularly in the unnecessary destruction of the dwindling forest resources. This destruction may be caused by (i) problems of rehabilitation, e.g. the Ramanagar settlement of the Kalinadi project (ii) the impact of labourers, e.g.the destruction of evergreen sholas on the Upper Nilgiri plateau (iii) the access to encroachers and poachers, e.g. Panshet and Kalinadi (iv) faulty planning, e.g. Linganamakki and Kalinadi. This destruction of forest cover has had a number of deleterious consequences in (i) worsening the shortages of forest resources, (ii) hastening the siltation of the reservoirs, (iii) ecological imbalances as in the rapid spread of Eupatorium in the Kalinadi project area and (iv) the decimation of biological diversity, as in the great reduction of evergreen forests in the Western Ghats, threatening the survival of lion-tailed macaque and the extinction of grass species, Hubbardia heptaneuron. It is stressed that the only sustainable and therefore true development is environmentally sound development. The interests of the weaker sections of the society often provide a good index of the soundness of the development from an environmental point of view. The planning of the development process with this perspective is a great scientific and technological challenge that must be taken up.
\end{abstract}

Keywords. Environmental impact; rehabilitation; deforestation; dams; hydroelectric projects; irrigation projects.

\section{Introduction}

A more intensive utilisation of the natural resources of the earth has underlain all economic development. Thus domestication of animals has concentrated the more dispersed populations of wild animals used by the hunter-gatherers, and irrigation has enhanced the supply of water to cultivated crops in previously rain-fed tracts. The natural resources of the earth are however finite and often interdependent. An intensification of the utilisation of one such resource can therefore lead to its exhaustion, even if it is a renewable resource, or to the deterioration of another interacting resource. It is now well known that historically an intensification of resource use has often resulted in its exhaustion and in many undesirable side effects with a consequent deterioration of the quality of human life (Thomas 1956). Although modernday technology has enhanced by several orders of magnitude man's ability to use the earth's natural resources, it has not overcome the traditional problems of overexploitation and of the deleterious impact on other natural resources. As a matter of fact, the magnitude of these problems has often become proportionately greater. 
Farvar \& Milton (1973) document a number of such consequences of what they term ' careless technology,' ranging from the outbreak of schistosomiasis following the construction of the Aswan dam in Egypt to the salinisation of large tracts of farmland following intensive irrigation in the Indus basin in Pakistan.

The ancient land of India abounds in many such examples, beginning perhaps with the man-induced desertification of Rajasthan (Bryson \& Barreis 1967). This vital problem has however received scant attention in our country, and the major global reviews of Thomas (1956) and Farvar \& Milton (1973) contain no significant material on India. Symptomatic of the near-total lack of our understanding of this problem is the fact that the exhaustive treatment by Rao (1975) of the water wealth of India and its utilisation makes only a passing reference to the environmental problems attendant on such utilisation.

The present paper is therefore a preliminary attempt at documenting a few specific aspects of the environmental consequences of the intensification of the utilisation of India's natural resources. In this paper, attention is focussed on the use of river waters through the construction of reservoirs on the Western Ghats in Peninsular India. The orography of the Western Ghats interacting with the winds of the southwest monsoon leads to the highest levels of precipitation for Peninsular India on the crestline of the Western Ghats. This heavy precipitation, coupled with the steep westward slopes of the Ghats renders this an ideal location for the generation of hydroelectric power, and many such projects, e.g. Koyna, Linganamakki, Upper Bhavani and Idikki, have been completed on this hill chain. The major eastward flowing rivers of Peninsular India-Godavari, Krishna and Kaveri all originate on the Western Ghats and the region where the hills of the Ghats merge with the Deccan Plateau furnishes ideal conditions for the construction of irrigation projects, and many such, e.g. Panshet, Kabini and Bhawanisagar, have been completed in recent years.

As has been the world-wide experience, these projects have tended to focus entirely on the construction of dams, canals, tunnels, pipelines and power-generating stations, with little attention to the other wide-ranging consequences of the projects (Farvar \& Milton 1973; Dasmann et al 1973). The Western Ghats today harbour almost the entire forest wealth of the states of Gujarat, Maharashtra, Goa, Karnataka, Tamilnadu and Kerala, and these forest resources are already seriously in short supply (Gadgil \& Prasad 1978). Moreover, the irrigation and hydroelectric projects have led to serious deforestation not just in the submersion areas, but in the vital catchment areas as well. This in turn has enhanced the soil erosion in the catchment and siltation of the reservoirs. It has sharply reduced the diversity of plant and animal life of this region, and has led to ecological disturbances. All of this has serious long-range economic consequences for the society as a whole, but its more immediate victims are the tribals and peasants of the Western Ghats (Darwin 1976; Anon 1977a).

These developments have received little systematic attention, apart from some references in the report of the Task Force (Anon 1977a) and two studies on the Kuttanad and Silent Valley projects (Kannan 1979; Prasad et al 1979). An attempt is made in this paper to document these developments with particular reference to loss of forest resources on the basis of the author's observations during the course of field work in various regions of the Western Ghats beginning in early 1972 (Gadgil and Vartak 1976; Prasad \& Gadgil 1977; Sastri et al 1977). The material 
presented here was incidental to the primary objectives of these studies, though it interested the author greatly from the very beginning. It could not however be collected as systematically and with as careful a quantification as one would have wished, for my understanding of the problem has unfolded only gradually. At this juncture, therefore, the material presented is only a preliminary statement which aims to define the problem, illustrate some of its aspects and suggest lines along which more careful and quantitative studies ought to be carried out.

Let us begin by presenting a case study, that of the Panshet reservoir in Pune district in somewhat greater detail to illustrate the various forces at play. The various factors directly or indirectly associated with dams which lead to a destruction of vegetation cover are then considered. This will be followed by an examination of the adverse consequences of this destruction, for the society in general, and for its weaker sections in particular.

\section{Impact of the Panshet Dam}

The Panshet reservoir is situated about $25 \mathrm{~km}$ to the west of Pune and has been created by the construction of dams on the rivers Mula and Mose (figure 1). The reservoir lies just to the east of the crestline of the Western Ghats at an altitude of about $600 \mathrm{~m}$. The terrain is very much broken with narrow valleys of less than half

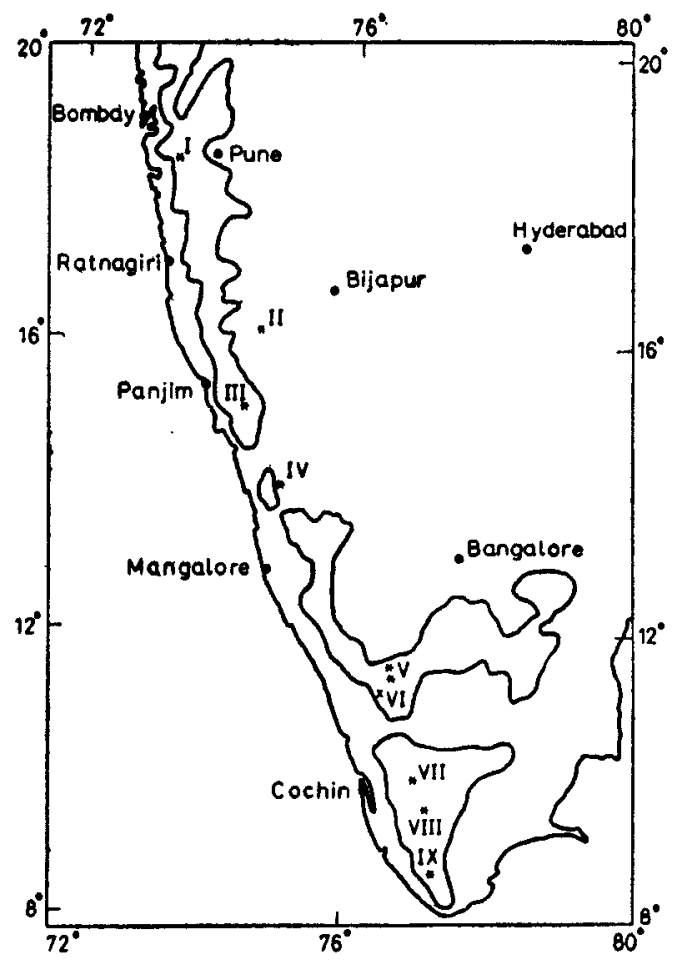

Figure 1. A map of Peninsular India showing locations of various sites referred to in the text.

I. Panshet, II. Hidkal, III. Kalinadi, IV. Linganamakki, V. Upper Nilgiri Plateau, VI. Silent valley, VII. Idikki, VIII. Periyar, IX. Mundanthurai-Kalakad 
a kilometre in extent separated by steep hills rising to altitudes of around $1200 \mathrm{~m}$. Before the construction of the reservoir, the peasants of this region grew paddy in the valleys and practiced shifting cultivation for millets on the lower hill slopes. These hill slopes had a good tree cover of mango (Mangifera indica) and harada (Terminalia chebula), for these cash-yielding trees used to be spared by the peasants while clearing for millet cultivation. The nuts of harada used extensively for tanning supported a flourishing industry at Bhor, some $50 \mathrm{~km}$ away. The upper hill slopes were clothed by a rich natural forest of the semi-evergreen type, constituted into state-owned forest reserves. These forests were hardly exploited due to the lack of transport facilities (Gadgil \& Vartak 1976).

The work on the Panshet reservoir commenced around 1955 with the construction of a good road linking this region to the city of Pune. The submersion region consisting of the valleys with the paddy fields and the lowermost hill slopes with mango and harada trees had to be deforested. There was a great demand from the city of Pune for the excellent charcoal that can be prepared from the harada trees. Consequently, not only the submersion area but the entire lower hill slopes constituting over half of the catchment area was denuded of tree cover by 1960 (figure 2, plate 1). Apparently this occurred because the timber merchants who came in to deforest the submersion area bought the trees on the large tracts of private lands on the hill slopes at throw-away prices by convincing the peasants that they were soon going to be resettled far away in the command area of the dam, and that it would be in their best interest to sell off the trees. Be that as it may, the process of resettlement began only in the 1970 s, a decade after this large-scale deforestation, and even today in 1979 , only a minority of the peasants have moved to the new area, the rest continuing to live on the hill slopes.

With the deforestation of the hill slopes, the top soil has eroded rapidly in the face of the heavy annual precipitation of over $4000 \mathrm{~mm}$, leading to large landslides by the early 1970s. This has depressed the productivity of the shifting cultivation, and consequently, the peasants have made large-scale encroachments in the reserved forest lands on the upper hill slopes for cultivation. The rich wild life including sambar, barking deer and wild pig that these hill slopes once harboured has all but disappeared with the destruction of the tree cover and the greater accessibility of the region to the well-equipped urban poacher. The peasants report that where they used to get a wild pig or deer once a week, they now hardly get a blacknaped hare once a month. With the disappearance of harada trees the regular cash income of the peasants has vanished and the harada-based industry at Bhor has been closed down. The very low amount realised by peasants through the sale of trees has been exhausted long ago. Although no data on siltation rates for Panshet are available, one has to merely see the eroded slopes and landslides to be convinced that they must be very high indeed.

It is evident that this devastation of the catchment, which in turn has led to the pauperisation of the inhabitants, the collapse of a forest-based industry, and siltation of the dam could have been forestalled if adequate measures to conserve the vegetation cover of the catchment were an integral part of the irrigation project. 


\section{Causes of deforestation}

The execution of an irrigation or a hydroelectric project need involve the loss of forest resources only in the submersion areas. Apart from this, the creation of a large water body could positively help the other existing forest and wild life. The nearly century-old reservoir on the Periyar river in the heart of the Thekkady wild life sanctuary provides an example of this possibility (figure 1). In the case of this reservoir, not even the submersion area was deforested and the ancient tree stumps stick out of the water to this date, providing excellent perches for the rich bird life of the area. The wild life too has benefitted from the provision of a large perennial water body. The forest cover in the vicinity has also been fairly well preserved. Unfortunately, it is not possible to cite such examples from more recent times, where almost all projects seem to have had a devastating effect on the surrounding forest resources in a number of ways. These may be classified as problems of (i) rehabilitation (ii) labourers (iii) access to encroachers and poachers and (iv) faulty planning.

\subsection{Rehabilitation}

A striking example of the problems of rehabilitation is provided by the settlement of Ramanagar for the refugees of the Kali hydroelectric project (figure 1). The township of Supa, along with a number of minor villages will be submerged by this project and these several thousand families have to be provided alternative land in lieu of their paddy fields, coconut and arecanut gardens and other rich agricultural and horticultural land. Since practically all of such land is already under cultivation, they have been provided a hectare of non-irrigated hilly land for every hectare of submerged land, which is mostly irrigated lowland. Incidentally, it is to be noted that no attempt is being made to provide the refugees with alternative non-agricultural occupation based on the large amount of electrical power that will be generated by this giant hydel project.

This settlement is expected to be established at a place called Ramanagar near Londha on the border of Belgaum and North Kanara districts of Karnataka. This tract of land was earlier under reserved forest, and was taken over for resettlement around 1975. At the time of handing over, the entire tree crop was removed, and the land was allowed to lie fallow without the institution of any soil conservation measures at least till 1979. This land has attracted not a single peasant settler from amongst the refugees who are staying on their lands while the construction of the Supa dam goes on in 1979. In the meanwhile the topsoil on these unprotected hill slopes in this catchment area of one of the Kali project reservoirs has eroded over the last four monsoons making it by 1979 a desert unfit for cultivation for all times. The landscape stands desolate with a few empty school and temple buildings the only sign of the planned township. The Kali hydel project refugees are in the meanwhile agitating to refuse to go to Ramanagar and demanding another rich forested site called Barchi for their resettlement.

The clearance of the forest on the land earmarked for resettlement was clearly a grave error. The original forest was rich in tree species of the genus Terminalia which could have served as a base for a flourishing tasar silk industry. This could have been supplemented by bee-keeping and production of minor forest produce such as harada (Terminalia chebula) nuts: The remaining less valuable trees could have 
been selectively cleared and cultivation of intervening patches of terraced and bunded land properly organised. This would have resulted in an economically more viable and ecologically sounder land use. Instead, the summary deforestation without the institution of any soil conservation measures has irreversibly ruined this large tract of land.

A second example of rehabilitation problems is provided by the Hidkal irrigation project on the Ghataprabha river in north Karnataka (figure .1). This reservoir nearing completion in 1979 is expected to eventually irrigate 2.63 lakh hectares in its command area, while it has submerged agricultural lands of only about 4000 hectares in extent. Nevertheless, the displaced population is not being rehabilitated in the irrigated command area, but rather in the catchment area, including places right on the fringes of the reservoir. The contribution of such settlements to increased siltation of the river is not documented, but appears to be significant.

\subsection{Labourers}

The execution of irrigation and hydroelectric projects involves the camping of several thousand labourers at the project sites. The labourers require timber for their huts and fuel for their day-to-day living, and so far they have always depended on the forest to meet these requirements. A notable example of the serious disturbance caused thereby to the forest is provided by the construction of Avalanche and other reservoirs on the Upper Nilgiri plateau (figure 1). These reservoirs are situated on a plateau at an altitude of around $2500 \mathrm{~m}$, and are a cold, wet and windswept region for ten months of the year. Some 20,000 labourers were camped on this plateau for about 7 years for the construction of the reservoirs. There were no special provisions for housing them, and they had to live in ramshackle huts. This they could do only by keeping the huts continually heated by burning logs of wood. All this wood came from the famous evergreen shola forests of Nilgiris. These forests, rich in a number of endemic species are restricted to the higher hill tops of the Western Ghats and have largely disappeared due to plantation and other activities (Blasco 1971). Vast tracts of these virgin forests on the upper Nilgiri plateau have thus disappeared due to the activity of the labourers who had no recourse but to cut them down in order to survive (John Joseph 1978). This could have been alleviated, if not altogether avoided, if the labourers could have been provided with some tin or asbestos sheds and regulated fuel supply. This fuel supply could at least in part have been based on the wood cleared from the submersion area.

\subsection{Access to encroachers and poachers}

Hydroelectric and irrigation projects often open up previously inaccessible regions rich in timber and wild life to new agricultural settlers and poachers of both timber and wild life. It is feared that the colonisation of areas rendered accessible by the Silent Valley project is already underway, and will lead to irreversible damage (Nair 1979; Prasad et al 1979) (see figure 1). These settlers are likely to follow the pattern of settlers in the Idikki area who have largely colonised steep slopes unfit for cultivation on a sustained basis without very heavy investment in soil conservation measures.

Wealthier and better organised poachers take advantage of the improved access 
facilities for smuggling out more valuable timber and poaching wild animals. These activities are naturally much more difficult to document. There is however considerable circumstantial evidence of this. For example, the once famous Dandeli wild life sanctuary was in 1977 on the verge of being dedeclared as a sanctuary because of the severe depletion of wild life consequent on the opening up of the area with the Kali hydroelectric project.

\subsection{Faulty planning}

Faulty planning of matters more directly concerned with the execution of the project as such has also led in a number of cases to an unnecessary loss of forest resources. Three examples, all from the state of Karnataka can be cited. The first example concerns the hydroelectric project on the Sharavathy river (figure 1). The large reservoir of Linganamakki feeding this project has filled to capacity only thrice since its commissioning some 20 years ago. This is because the estimated inflow into the reservoir from its catchment has not materialised. If the dam height had been restricted to a lower level such that the reservoir would be filled more regularly, not only would the cost of the project have been substantially reduced, but several thousand hectares of forest would also have been saved (Sharma 1978). As it is, the river Chakra is now being dammed, submerging further forest areas in Hosanagar Forest Range merely to feed further water to the Sharavathy hydel project. Moreover, the deforested upper submersion area of Linganamakki reservoir that rarely goes under water is under active cultivation most of the time, and must considerably add to the siltation of the reservoir.

The two other examples are from the Kali hydel project. A most elementary mistake has been committed at the Tattihalla dam site where some clearance area was incorrectly demarcated. As a consequence, considerable forest land (e.g. block 20, compartment 6 of the Sambrani Range) was unnecessarily deforested. Attempts are being made to put this back under teak plantation, but the Eupatorium weed, to which we will refer in $\S 4.3$ below, makes such attempts difficult.

The last example is from Ambikanagar, the township created in place of the villages Amba-Jumba for the Kali hydel project. This area in the heart of the Dandeli wild life sanctuary was a forest famous for its herds of gaur. It was totally deforested at the time of its being handed over for the township. In the humid heat of the West coast, it is now a desolate and dusty place. It would have been a lovely hill resort, with its picturesque Syke's point if only such trees as were essential for roads and buildings were removed. As it is, all that Ambikanagar now has are a few small saplings planted by the roadside.

\section{Consequences}

The author believes that he has given enough indications, albeit qualitative, of the considerable magnitude of the loss of forest vegetation accompanying the irrigation and hydroelectric projects. This loss has a variety of consequences, all of which ought to be accounted for in the cost calculations of the project. These consequences may be considered under the following heads: (i) scarcity of forest produce, (ii) siltation of the reservoirs, (iii) ecological imbalances and (iv) decimation of biological diversity. 


\subsection{Searctty of forest produce}

The mounting scarcity of forest products in India has been well-documented as, for example, in the perspective plan for forests of Karnataka (Anon 1977b). The loss of forest land associated with projects has been a major factor aggravating this situation. Here, just one example may be cited from our own studies on the bamboo resources of Karnataka (Gadgil \& Prasad 1978). Bamboo is the poor man's timber as well as the major raw material for the manufacture of paper in India. The yearly consumption of bamboo in Karnataka is around 160,000 tonnes while the yearly increment to the crop is only around 135,000 tonnes. This overexploitation has led to the wiping out of bamboo from many areas earlier rich in bamboo crop. As bamboo grows well along water courses, submersion under reservoirs hits bamboo particularly hard. Various projects in Kartnataka have therefore been a major factor contributing to the bamboo famine.

\subsection{Siltation of reservoirs}

The maintenance of a proper cover of vegetation in the catchment area of any reservoir is vital to its proper functioning. Such vegetation regulates the flow of water into the reservoir, preventing floods and maintaining water flow in the dry season, and more crucially prevents excessive erosion of soil (Dasmann et al 1973; Pareira 1973). That soil erosion in the catchment area and the consequent siltation of reservoirs has been a major problem in India is well-known (Anon 1978). Thus, for the 18 reservoirs all over India for which data are available, the observed siltation rate has exceeded the expected siltation rate in all but one of the cases. Moreover, the observed rate is generally 3 to 10 times as high as the expected siltation rate. The consequent drastic reduction in the useful life of the reservoirs has obviously serious economic implications, as for example, has been pointed out by Verghese (1977) for the greater Ganga river system. Although no data are immediately available for the Western Ghats reservoirs, it is evident that siltation must be a major problem.

\subsection{Ecological imbalances}

Apart from the more evident loss of forest wealth and siltation of the reservoirs, the large-scale deforestation for the projects can lead to subtler ecological imbalances. One such has been the enormous increase in the population of the weed Eupatorium glandulosum in the Kali hydel project area. This composite weed of the moister forests smothers out all tree growth in clear-felled forest areas and is totally unpalatable to all herbivorous animals. It renders forests more susceptible to fire and to losses of minerals through leaching. This weed of the moist forests of the Western Ghats has come to Kerala from Assam and has rapidly spread northward from there. When the Supa and other submersion areas of the Kali hydel project were deforested some five years ago, Eupatorium had just begun to establish itself in North Kanara. The vast stretches of clear-felled forest land provided the optimum habitat for Eupatorium which has now totally clothed these areas. It spreads far and wide through its wind-borne seeds. The vast population of Eupatorium in the deforested Kali submersion area is likely to be serving as a major infective centre for the further spread of this weed into Belgaum-Goa-Savantwadi-Kolhapur areas, and into the many new plantations being taken up in North Kanara itself. 


\subsection{Decimation of biological diversity}

The tremendous genetic diversity of living organisms created by the hundreds of millions of years of evolution is a precious heritage of man. These have yielded to us a variety of foods, fibres and vital drugs and their maintenance is crucial to further progress in these fields. This is why the Food and Agricultural Organisation of the United Nations has launched a vigorous programme for the maintenance of genetic diversity of wild relatives of cultivated plants. The Western Ghats harbour a large variety of these, ranging from ragi, paddy, cardamom and pepper to mango and jackfruit. The critical importance of preserving all genetic diversity, not just that of presently utilised species, is also what has prompted the U.S. Supreme Court to hold up a dam that will destroy the only known population of a small fish-the snail darter.

The large impact of the irrigation and hydroelectric projects on the Western Ghats has sharply reduced the biological diversity of this region. These projects have selectively affected high rainfall areas, and areas near water-courses which tend to harbour evergreen tree species. They have thus contributed to the sharp reduction in the extent of evergreen forests on the Western Ghats (Pascal \& Meher-Homji 1978). These forests have been a unique storehouse of many plant and animal species occurring nowhere else in the world, and it is only our profound ignorance which has masked the many extinctions of biological species-the many snail darters -that must have vanished. Father Saldanha (1979) points to just one example, Hubbardia heptaneuron Bor, a grass that was once known to grow in the spray zone of the famous Jog Falls of Sharavathy and nowhere else in the world. This species has apparently gone extinct with the execution of the Sharavathy power project.

Another threatened species of the Western Ghats is a monkey, the lion-tailed macaque (Macaca silenus). There are now only two surviving viable populations of this monkey left in the world. One of these is in the Silent Valley and the other in the Mundanthurai-Kalakad sanctuaries near the Agastyamalai peak (figure 1). This monkey depends for its survival on trees of genus Cullenia, and if the Silent Valley hydroelectric project materialises, most of this Cullenia forest will be submerged and the monkey wiped out. The Mundanthurai-Kalakad population is also threatened by other impending projects in that area. For all we know, with this monkey we may lose the only biological material that may enable us to combat some future epidemic of a new mutant of encephalitis.

\section{Conclusions}

\subsection{Sustainable development}

As we stressed at the beginning, economic development ultimately depends on the intensification of the use of the earth's natural resources. For a true development, however, this process should not lead to a rapid exhaustion of the resource being tapped, nor should it be accompanied by a needless destruction of another resource. This suggests that we should be particularly concerned about maintenance of the long life of the reservoirs, and avoiding the adverse consequences on other resources such as soil, forest and wild animals. Only by aiming at development that retains 
its harmony with nature, by aiming at environmentally sound development, will we achieve true and sustainable development.

Our current development effort obviously fails in many ways when viewed from this perspective. Why is it then that these failures have attracted so little attention so far in our country? The author believes that this is so because the urbanised decision-makers are several stages removed from direct dependence on the natural resources, and are therefore immune from the immediate negative consequences of the unbalanced development process. It is the local peasants and tribals depending much more directly on the natural resources that bear the brunt of the immediate negative consequences of the development process (Bahuguna 1978; Kannan 1979; Mishra \& Tripathi 1978).

This is well illustrated by the first case study. The destruction of the tree cover in the catchment immediately profited the urban society of Pune by providing cheap wood charcoal. The tremendously increased siltation rate would no doubt affect this city population in the coming years by reducing the life of the reservoir which supplies water to the city. These effects would however be felt only over several decades. The local peasants on the other hand have come to suffer much more rapidly, by the reduction in fertility of their hill slope land and the reduction in the availability of wild animal protein.

The author would therefore like to suggest that the interests of these weaker sections of our society provide a very good index of how harmonious with the environment, and thus how sound a development project is. If these interests are given serious consideration, we will orient ourselves towards planning of the overall land use for the long-term sustained utilisation of soil, water, vegetation and animal resources and it is only then that we will turn to planning for true, sustainable development.

\subsection{Perspectives for future work}

The concept of environmentally sound development throws up a whole series of scientific and technological challenges. Our whole scientific and technological establishment is geared today towards the solution of such problems as: how can we, over the next five years, extract the maximum amount of power out of the rivers of North Kanara? Even this problem is posed in isolation of another typical problem: how can we, over the next five years, produce the maximum amount of paper out of the forests of North Kanara? The point of view sketched above suggests that the scientific and technological establishment ought to address itself to a very different kind of problem, namely, how can the whole gamut of natural resources of North Kanara be developed so as to improve on a long-term basis the quality of life of the weaker sections of the society of North Kanara? We would then think not just of the power requirements of the Kudremukh Iron Ore complex, but also of the fuelwood requirement of the people of North Kanara and of why all the avenue trees on the Sagar road are being chopped down. We would also think of bamboo requirements for rural housing in North Kanara, and not just turn to bagasse production for our paper factories once the bamboo stocks of North Kanara are finished. We will then plan the resettlement of refugees of the Supa dam as carefully as we plan the details of the powerhouses for the Kali hydroelectric project. It is an exciting soientific and technological challenge that deserves to be taken up. 
The field work on which this paper is based has been supported at various times by the Indian Institute of Science, Maharashtra Association for Cultivation of Science, Karnataka State Council for Science and Technology, Kale Education Trust, World Wildlife Fund, Department of Science and Technology, University Grants Commission and the International Union for Conservation of Nature and Natural Resources. The author has discussed the issues and learnt much from many peasants, tribals, administrators, scientists and engineers. He was greatly helped in the preparation of the present paper by Sulochana Gadgil, A J T Johnsingh, S Narendra Prasad, A K N Reddy and $R$ Narasimha.

\section{References}

Anon 1977a Report of the task force for the ecological planning of the development of Western Ghats, National Committee on Environmental Planning and Co-ordination, Bangalore, pp. 20

Anon 1977b Perspective plan for forests of Karnataka (Bangalore), Report of Karnataka Forest Department

Anon 1978 Joint Commissioner (Sc-F): statement showing rate of siltation etc. under the centrally sponsored scheme of soil conservation, Ministry of Agriculture and Irrigation, Government of India

Bahuguna S L 1978 Voluntary Action 2018

Blasco F 1971 Inst. Fr. Pondichery Tr. Sect. Sci. Tech. 11436

Bryson R A \& Barreis D A 1967 Bull. Am. Meterol. Soc. 48136

Darwin C E 1976 Seminar on hydropower and environment, Georgetown, pamphlet

Dasmann R F, Milson J P \& Freeman P H (eds.) 1973 Ecological principles for economic development (London: John Wiley) pp. 252

Farvar M T \& Milton J P (eds.) 1973 The careless technology: ecology and international development (New York: Natural History Press) pp. 1030

Gadgil M \& Prasad S N 1978 Commerce 1361000

Gadgil M \& Vartak V D 1976 Econ. Bot. 30152

John Joseph 1978 Personal communication

Kannan K P 1979 Socio-economic and ecological consequences of water control projccts: the case of Kuttanad in Kerala (India) (Trivandrum: Centre for Development studies) pp. 39

Mishra A \& Tripathi S 1978 Chipko movement (New Delhi: Gandhi Book House) p. 37

Nair N C 1979 Personal communication

Pareira H C 1973 Land use and water resources in temperate and tropical climates (London: Cambridge University Press) pp. 246

Pascal and Maher-Homji 1978 Personal communication

Prasad M K, Paramcswaran M P Damodaran V K, Nair K N S \& Kannan K P 1979 The Silent Valley Hydroelectric Project: a techmo-economic and socia-political assesment (Trivandrum: Kerala Sastra Sahitya Parishad) pp. 61

Prasad S N \& Gadgil M 1977 Conservation of bamboo resources of Karnataka: a preliminary report (Bangalore: Karnataka State Council for Science and Technology) pp. 50

Rao K L 1975 India's water wealth: its assessment, uses and projections (New Delhi: Orient Longman) pp. 255

Saldanha Rev Fr C J 1979 Personal communication

Sastri P, Gadgil M \& Malhotra K C 1977 A proposal for the compatible development of animal husbandry and forestry interests of North Kanara (Bangalore: Karnataka State Council for Science and Technology) pp. 60

Sharma Y M L 1978 Personal communication

Thomas W L (ed.) 1956 Man's role in changing the face of the earth; (Chicago: University Press) vols 1 and 2

Verghese B G 1977 Gift of the greater Ganga, Coromandel Lecture 8 (New Delhi: Coromandel Fertilisers Ltd.) p. 53 